\title{
Case of wide calibre false urethral passage in a patient of urethral stricture
}

\author{
Kaushal Kumar Gupta, Siddharth Pandey, ${ }^{\circledR}$ Saqib Mehdi, Manoj Kumar
}

Department of Urology, King George's Medical University, Lucknow, Uttar Pradesh, India

Correspondence to Dr Saqib Mehdi, mehdisaqib79@gmail.com

Accepted 7 February 2019

\section{DESCRIPTION}

A 50-year-old man presented to us with complaints of dysuria and narrowing of urinary stream after multiple attempts at catheterisation due to acute urinary retention following hernioplasty under spinal anaesthesia at some other hospital. Patient did not reveal the history of passage of a hard instrument like introducer via his urethra nor was it mentioned in the discharge notes of the patient. Patient had history of urethral stricture disease for which he had underwent endoscopic dilatation about 5 years back, although patient was not symptomatic for urethral stricture disease at the time of surgery. The urine analysis and routine blood investigations of the patient were unremarkable. We performed a retrograde urethrography of the patient, which showed the presence of two wide calibre passages in the region of prostatic urethra both opening at the level of verumontanum (figure 1). This radiological picture made it difficult to discern the true urethral passage from the false one, so urethroscopy of the patient was contemplated. On urethroscopy, two openings were visible in the bulbar urethra (figure 2). We gently probed the lower urethral mucosal bud with a guidewire and negotiated it into urinary bladder with ease. Gentle urethroscopy along guidewire revealed it to be the

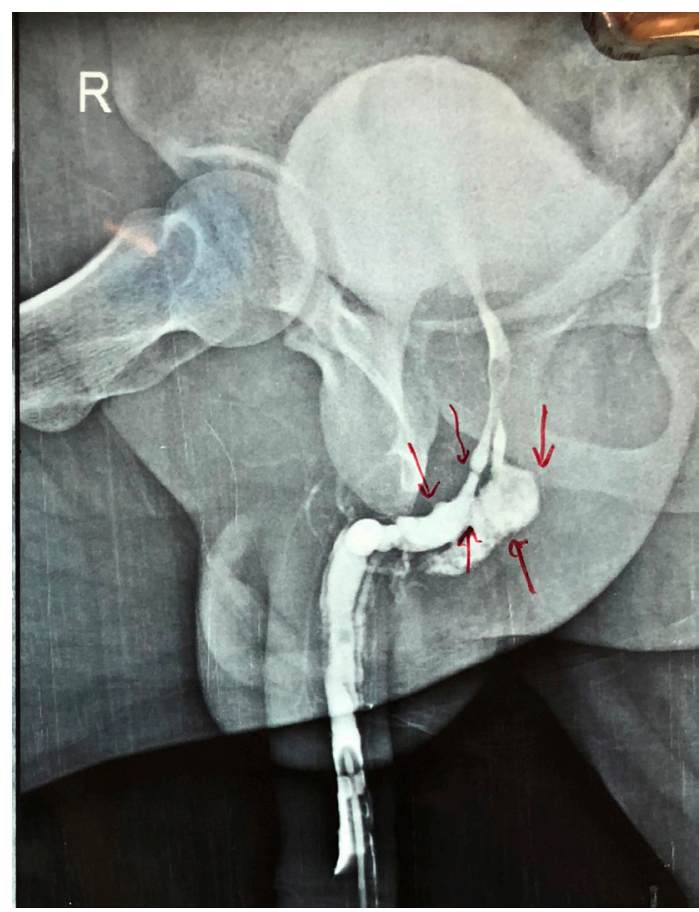

Figure 1 Rerograde urethrogram of the patient showing the presence of a wide calibre false passage running parallel to the urethra (red arrows).

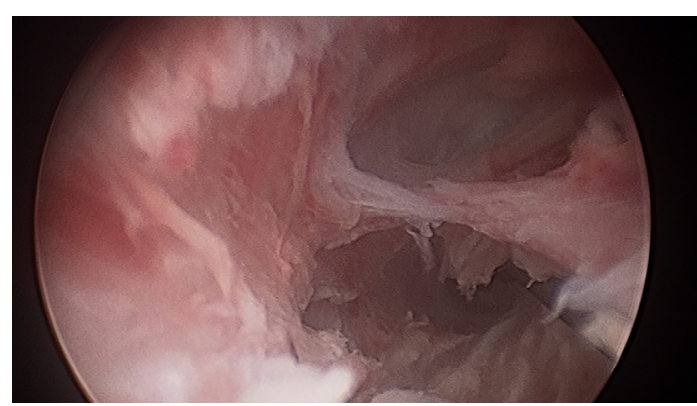

Figure 2 Endoscopic view showing the opening of the true urethral lumen and the false passage just proximal to the verumontanum.

true urethral passage opening into the bladder while inspection of the other parallel passage revealed it to be a blind ending false passage. With the aid of an optical urethrotome, we incised the floor of the false passage guided by the guidewire along the urethra and negotiated a 16 Fr Foley catheter over guidewire into the urinary bladder. The catheter was kept in situ for 7 days. Patient was voiding well after 2 months of follow-up without any complaints of dysuria or thinning of urinary stream.

Catheterisation is a common procedure done after major surgeries at many centres in the world. Although being a common procedure, complications like trauma to urethra, haematuria, infection and acute urinary retention due to inflation of balloon of Foley catheter in urethra are frequently encountered. In our case, the patient developed a false passage contiguous to the urethra due to repeated attempts at catheterisation done for acute urinary retention after undergoing hernioplasty for right inguinal hernia. ${ }^{12}$ The creation of a false passage and stricture urethra are the most common complications of attempted catheterisation per urethra. These cases require a careful and complete

\section{Learning points}

Patients with a history of urethral stricture should be catheterised gently and preferably over a guidewire.

- In wide calibre false passages alongside the urethra, it may be difficult to discern the true urethral lumen on retrograde urethrography only.

- Urethroscopy serves as an important adjunct to retrograde urethroscopy in ruling out a large calibre false passage running contiguous to the urethra. 


\section{Images in...}

endoscopy of the urethra to ward off mistaking a false passage for the true urethral lumen. ${ }^{3}$

Contributors SM conceived the case report. SM and KKG were major contributors towards writing the manuscript. KKG, SP and MK treated the patient and also interpreted the patient data. SM and SP were involved in the review. All authors read and approved the final manuscript.

Funding The authors have not declared a specific grant for this research from any funding agency in the public, commercial or not-for-profit sectors.

Competing interests None declared.
Patient consent for publication Obtained.

Provenance and peer review Not commissioned; externally peer reviewed.

\section{REFERENCES}

1 Lowthian P. An uncommon complication of urethral catheterization. Br J Urol 1996;78:805.

2 St Luce S, Ninan AC, Hall JA, et al. Role of transrectal ultrasonography in diagnosis and treatment of retained Foley catheter. Urology 2005;65:1001.

3 Sotolongo JR, Gribetz ME. Large caliber urethral false passage after catheterization: a case report. J Urol 1982;128:819-20.

Copyright 2019 BMJ Publishing Group. All rights reserved. For permission to reuse any of this content visit

https://www.bmj.com/company/products-services/rights-and-licensing/permissions/

BMJ Case Report Fellows may re-use this article for personal use and teaching without any further permission.

Become a Fellow of BMJ Case Reports today and you can:

Submit as many cases as you like

- Enjoy fast sympathetic peer review and rapid publication of accepted articles

Access all the published articles

Re-use any of the published material for personal use and teaching without further permission

For information on Institutional Fellowships contact consortiasales@bmjgroup.com

Visit casereports.bmj.com for more articles like this and to become a Fellow 